\title{
The Distribution of Black Flies (Simulium Species) In Ugbem and Ukwepeyiere Communities of Biase Local Government Area of Cross River State, Nigeria.
}

\author{
Akpan, S. S., ${ }^{1}$, Alaribe, A. A. A. ${ }^{2}$ Ejezie, G.C. \\ ${ }^{1,2}$ Department Of Medical Laboratory Science, College Of Medical Sciences, University Of Calabar,P. M. B. \\ 1115, Calabar-Nigeria.
}

\begin{abstract}
The distribution of Simulium species was studied at 2 breeding sites in Ugbem and Ukwepeyiere Communities after 10 rounds of Ivermectin distribution. At each breeding site, 2 fly catchers worked alternately for 4 hours, both giving $a$ total of 8 hours from 8 a.m. to 3 p.m., each day. Flies were caught on 3 consecutive days, each month, from 8 a,m. to 3 p.m. between January and June, 2008. A total of 3895 Simulium flies were caught and identified using morphologic characteristics as Simulium sirbanum(70.5\%) and S. yahense (29.5). A total of $12.1 \%$ of both species were parous while $87.9 \%$ were nulliparous flies. Generally, more flies were caught in the morning (7 a.m. to 11 a.m.) than afternoon (12 noon to 3 p.m.) hours, in both dry and rainy seasons. No larva of Onchocerca volvulus was detected after dissection of both parous and nulliparous flies. This study has identified, for the first time, the species of Simulium flies which are prevalent in the study area.

Keywords: Distribution, Onchocerciasis, Simulium species.
\end{abstract}

\section{Introduction}

Simulium damnosum sensu lato is a complex group of over 40 sibling species of blackfly distributed throughout the sub-Saharan Africa and the Arabian peninsula (Cupp, 1996). They are responsible for more than 90 per cent of onchocerciasis cases worldwide and 95 per cent of cases in Africa (WHO, 2003). About 54 species of Simulium have been reported to bite man, transmitting onchocerciasis (Adler, et al., 2004).

Blackflies breed in fast-flowing streams and rivers with the velocity of about 50 centimetres per second (Leveque, 1989). Members of the Simulium damnosum s.l. can breed in a variety of aquatic habitats located in the Guinea or Sudan savannah, forest or transitional geo-botanic zones. For example, S. damnosum sensu stricto and S.sirbanum are found in large rivers of Uganda, southern Sudan and across the West African savannahs.

In these habitats, their population dynamics are regulated, primarily, by seasonal changes in rainfall. Long distance migration of inseminated gravid females also occurs during the rainy season as a feature of the biology of the savannah forms (Cupp, 1996). Simulium yahense is another cytospecies which is found in small streams and forested areas. Adults of this species remain developmentally active throughout the year. They are nonmigratory and tend to remain close to their aquatic habitats (Cupp, 1996).

Large swarms of black flies can often attack people, causing a considerable nuisance (Butler \& Hogsette, 1998). In sensitized individuals, reactions to blackfly saliva injected at the site of feeding may cause a syndrome known as "blackfly fever", which consists of headache, fever, nausea and, often, inflammation of lymph nodes (Harwood \& James, 1979). The presence of fast-flowing streams and rivers is a natural factor, which favours the breeding of Simulium species in the study area. Knowledge about the various species and their bionomics will enhance the formulation of strategies for the control of onchocerciasis in the area.

\section{Materials And Methods}

The Study area and population

Ugbem and Ukwepeyiere are two rural communities in Biase Local Government Area of Cross River State, Nigeria. The communities lie in the midst of tropical rain forests and are located about 112 kilometres North West of Calabar, the state capital. There is an estimated population of about 3,000 and 1,200 people in Ugbem and Ukwepeyiere, respectively. Dermatological lesions suggestive of onchocerciasis (e.g. subcutaneous nodules, leopard skin and elephantiasis) were observed among some residents of both communities.

There is no electricity or pipe-borne water in these communities. The people depend on rainwater, streams and rivers as sources of their drinking water. The major occupations of the people of both communities include farming, hunting, fishing and trading. The major food crops planted in the area include plantain (Musa paradisiaca), cassava (Manihot esculentum), maize (Zea mays), yam (Dioscorea rotundata) and cocoyam (Colocasia esculentum). Livestock such as goats (Capra hircus), sheep (Ovis aries) and domestic fowl (Galus galus) roam about freely. 
Cross River State lies within the rain forest belt, with an annual temperature range of 28 to $33^{\circ} \mathrm{C}$, rainfall of $2,500 \mathrm{~mm}$ and a high relative humidity of 77 to 84 per cent (Coluzzi, et al., 1979). This study was carried out from January to June, 2009.

\section{Catching of adult black flies}

The human-bait catch technique was used for catching adult black flies (Barbiero \& Trpis, 1984). Fly catching started from 7 a.m. to 3 p.m. over 3 consecutive days per month and lasted from January to June, 2009. January to March represented the dry season and April to June represented the rainy season. At each breeding site, two flycatchers worked alternately for 4 hours to make a total of 8 hours per catching day.

\section{Speciation and determination of parity of adult black flies}

At the field, each fly was carefully transferred into a test tube containing a cotton wool plug soaked with chloroform, in order to immobilize the fly. When quiescent, each fly was placed in a drop of normal saline on a clean slide and examined under a dissection microscope (Wild Heerbrugg M1B; Binoculars x 8/21). The speciation of the flies was done by studying their morphological characteristics whereas the determination of parity was done by studying the ovariole characteristics (Nwoke, 1993).

\section{Determination of infection rates}

Both parous and nulliparous flies were placed in separate universal containers holding $5 \mathrm{ml}$ of Carnoy's fluid (i.e. 1 part of glacial acetic acid +3 parts of absolute ethanol) (Hamada \& Adler, 1998; Currie \& Adler, 2000; McCreadie et al., 2005). The flies were further processed at the Parasitology Laboratory of the University of Calabar Teaching Hospital. The flies were stained with Mayer's acid haemalum for 5 minutes before bluing in water for 15 minutes (Atting, 2000). Each stained fly was dissected by teasing the head, thorax and abdomen separately, in a drop of normal saline on a clean glass slide.

The preparations were examined for larvae of $O$. volvulus under a dissection microscope (Wild Heerbrugg M1B; Binoculars x 8/21).

\section{Collection of eggs, larvae and pupae}

Eggs, larvae and pupae were collected as described by Service (Service, 1993). The larvae were identified using morphological keys (Nwoke, 1993).

\section{RESULTS}

A total of 3,895 black flies were caught between January and June, 2009. Two species of Simulium were prevalent at the two breeding sites, viz.: Simulium sirbanum (70.5\%) and S. yahense (29.5\%). Wing tufts of $S$. sirbanum are pale without markings whereas those of $S$. yahense are pale with black spots. Also, abdominal tubercles of larvae of $S$. sirbanum are tiny whereas those of $S$. yahense are prominent. Field observation showed that these two species of Simulium preferred to bite below the knees. The remaining 424 (10.9\%) of S. yahense were caught at Ukwepeyiere breeding site. Overall, 12.1 per cent of the total flies were parous, whereas the remaining 87.9 per cent were nulliparous. Among parous flies, 8.2 per cent were $S$. sirbanum, while 3.9 per cent were $S$. yahense. Of the parous flies, 4.75 per cent was caught during the dry season (Table 1). During the rainy season, 7.39 per cent of parous flies was caught (Table 2)

On the average, a monthly parous biting rate (MPBR) of 309.8 bites were recorded in the two communities during the dry season (Table 1). During the rainy season, an average MPBR of 485.6 bites was recorded in the two communities (Table 2).

The highest monthly parous biting rates (MPBRs) were recorded in April and May. In April, MPBR values of 810 and 340 were recorded at Ugbem and Ukwepeyiere, respectively. In May, MPBR values of 661.3 and 382.3 were recorded at Ugbem and Ukwepeyiere, respectively, (Table 2). No larva of $O$. volvulus was recorded from the dissected flies. The eggs, larvae and pupae of both species of Simulium were usually found attached to the leaves of an aquatic plant. Pandanus candelabrum. 
The Distribution Of Black Flies (Simulium Species) In Ugbem And Ukwepeyiere Communities Of TABLE 1 A summary of the entomological parameters recorded from January to June, 2008. (DRY SEASON)

\begin{tabular}{|c|c|c|c|c|c|c|c|c|}
\hline MONTHS & JANUA & $\mathbf{R Y}$ & FEBR & JARY & MARC & & & \\
\hline $\begin{array}{l}\text { PARAMETER } \\
\text { S }\end{array}$ & $\begin{array}{l}\text { UGB } \\
\text { EM }\end{array}$ & $\begin{array}{l}\text { UKWEPE } \\
\text { YIERE }\end{array}$ & $\begin{array}{l}\text { UGB } \\
\text { EM }\end{array}$ & $\begin{array}{l}\text { UKWEPEY } \\
\text { IERE }\end{array}$ & $\begin{array}{l}\text { UGB } \\
\text { EM }\end{array}$ & $\begin{array}{l}\text { UKWEP- } \\
\text { EYIERE }\end{array}$ & $\begin{array}{l}\text { TOTA } \\
\text { L }\end{array}$ & $\begin{array}{l}\text { AVERA } \\
\text { GE }\end{array}$ \\
\hline $\begin{array}{l}\text { No. of } \mathrm{S} . \\
\text { Sirbanum }\end{array}$ & 343 & 287 & 238 & 206 & 197 & 100 & 1371 & - \\
\hline $\begin{array}{ll}\begin{array}{l}\text { No. of } \\
\text { yahense }\end{array} & \text { S. } \\
\end{array}$ & 138 & 95 & 82 & 70 & 92 & 52 & 529 & - \\
\hline $\begin{array}{l}\text { Total flies } \\
\text { caught }\end{array}$ & 481 & 382 & 320 & 276 & 289 & 152 & 1900 & - \\
\hline Nulliparous files & 449 & 356 & 299 & 244 & 240 & 127 & 1715 & - \\
\hline Parous flies & 32 & 26 & 21 & 32 & 49 & 25 & 185 & - \\
\hline $\begin{array}{l}\% \text { age of Parous } \\
\text { Flies }\end{array}$ & 0.82 & 0.67 & 0.54 & 0.82 & 1.26 & 0.64 & 4.75 & $(0.79)$ \\
\hline $\begin{array}{ll}\text { Parous } & \text { S. } \\
\text { Sirbanum } & \end{array}$ & $\begin{array}{l}19(0.4 \\
9)\end{array}$ & $18(0.4 .6)$ & $\begin{array}{l}14(0 . \\
36)\end{array}$ & $23(0.59)$ & $\begin{array}{l}28(0 . \\
72)\end{array}$ & $16(0.41)$ & 118 & (3.03) \\
\hline $\begin{array}{ll}\begin{array}{l}\text { Parous } \\
\text { yahense }\end{array} & \text { S. } \\
\end{array}$ & $\begin{array}{l}13(0.3 \\
3)\end{array}$ & $8(0.21)$ & $\begin{array}{l}7(0.1 \\
8) \\
\end{array}$ & $9(0.23)$ & $\begin{array}{l}21(0 . \\
54)\end{array}$ & $9(0.23)$ & 67 & $(1.72)$ \\
\hline Flies with Larva & - & - & - & - & - & - & - & - \\
\hline Infection Rate & - & - & - & - & - & - & - & - \\
\hline $\begin{array}{ll}\text { Monthly Biting } \\
\text { Rate }\end{array}$ & $\begin{array}{l}4970 . \\
3 \\
\end{array}$ & 3947.3 & $\begin{array}{l}2986 . \\
7 \\
\end{array}$ & 2576 & $\begin{array}{l}2986 . \\
3 \\
\end{array}$ & 1570.7 & - & 3172.9 \\
\hline $\begin{array}{l}\text { Monthly Parous } \\
\text { Biting Rate }\end{array}$ & 330.7 & 268.7 & 196 & 298.7 & 506.3 & 258.3 & - & 309.8 \\
\hline
\end{tabular}

TABLE 2:

A summary of the entomological parameters recorded from January to June, 2008.

(RAINY SEASON)

\begin{tabular}{|c|c|c|c|c|c|c|c|c|}
\hline MONTHS & \multicolumn{2}{|c|}{ APRIL } & \multicolumn{2}{|c|}{ MAY } & \multicolumn{2}{|l|}{ JUNE } & & \\
\hline PARAMETERS & $\begin{array}{l}\text { UGB } \\
\text { EM }\end{array}$ & $\begin{array}{l}\text { UKWEPE } \\
\text { YIERE }\end{array}$ & $\begin{array}{l}\text { UGB } \\
\text { EM }\end{array}$ & $\begin{array}{l}\text { UKWEPE } \\
\text { YIERE }\end{array}$ & $\begin{array}{l}\text { UGBE } \\
\mathrm{M}\end{array}$ & $\begin{array}{l}\text { UKWEPE } \\
\text { YIERE }\end{array}$ & $\begin{array}{l}\text { TOT } \\
\text { AL }\end{array}$ & $\begin{array}{l}\text { AVER } \\
\text { AGE }\end{array}$ \\
\hline $\begin{array}{l}\text { No. of } \mathrm{S} \text {. } \\
\text { Sirbanum }\end{array}$ & 247 & 142 & 315 & 211 & 285 & 175 & 1375 & \\
\hline No. of S. yahense & 101 & 52 & 150 & 80 & 162 & 75 & 620 & \\
\hline Total flies caught & 348 & 194 & 465 & 291 & 447 & 250 & 1995 & \\
\hline Nulliparous files & 267 & 160 & 401 & 254 & 402 & 223 & 1707 & \\
\hline Parous flies & 81 & 34 & 64 & 37 & 45 & 27 & 288 & \\
\hline $\begin{array}{l}\% \text { age of Parous } \\
\text { Flies }\end{array}$ & 2.08 & 0.87 & 1.64 & 0.95 & 1.16 & 0.69 & 7.39 & (1.23) \\
\hline $\begin{array}{ll}\text { Parous } & \text { S. } \\
\text { Sirbanum } & \end{array}$ & $\begin{array}{l}55(1 . \\
41)\end{array}$ & $26(0.67)$ & $\begin{array}{l}42(1 . \\
08)\end{array}$ & $26(0.67)$ & $\begin{array}{l}29(0.7 \\
4)\end{array}$ & $22(0.56)$ & 200 & $(5.17)$ \\
\hline Parous S. yahense & $\begin{array}{l}26(0 . \\
67)\end{array}$ & $8(0.21)$ & $\begin{array}{l}22(0 . \\
56)\end{array}$ & $11(0.28)$ & $\begin{array}{l}16(0.4 \\
2)\end{array}$ & $5(0.13)$ & 88 & (2.18) \\
\hline Flies with Larva & - & - & - & - & - & - & - & - \\
\hline Infection Rate & - & - & - & - & - & - & - & $=$ \\
\hline $\begin{array}{l}\text { Monthly Biting } \\
\text { Rate }\end{array}$ & 3480 & 1940 & 4805 & 3007 & 4470 & 2500 & - & 3367 \\
\hline $\begin{array}{l}\text { Monthly Parous } \\
\text { Biting Rate }\end{array}$ & 810 & 340 & 661.3 & 382.3 & 450 & 270 & - & 485.6 \\
\hline
\end{tabular}




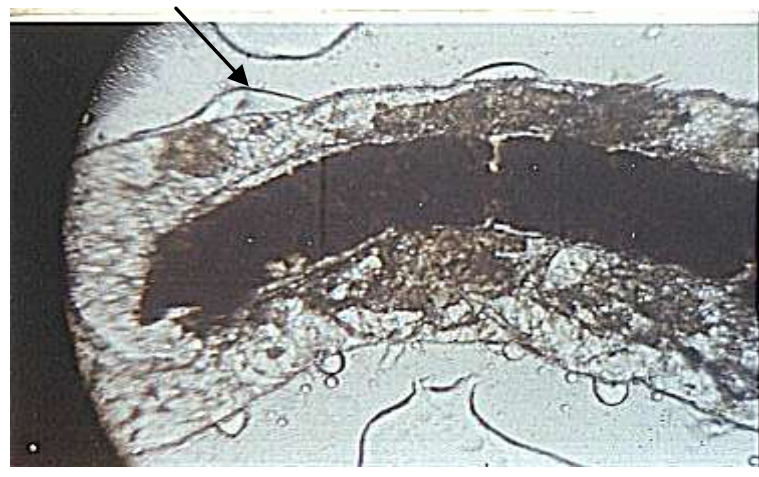

FIG. 1A Shows a larva of $S$. yahense with prominent abdominal tubercles.

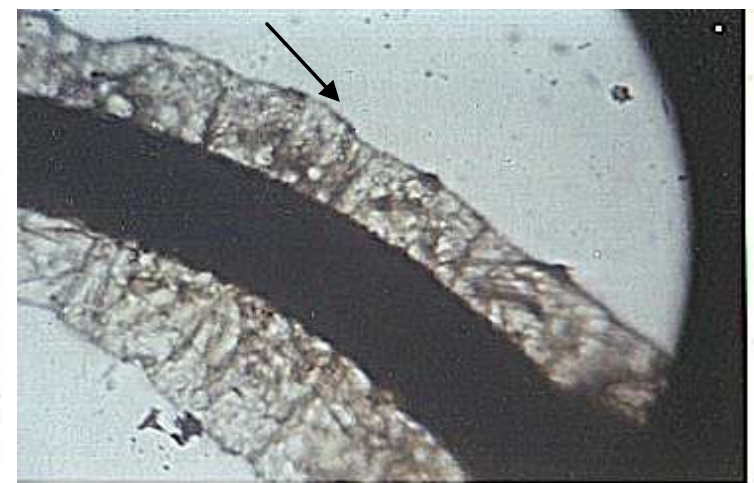

FIG.1B Shows a larva of $S$. sirbanum with small abdominal tubercles.

\section{Conclusion}

This study has identified two species of Simulium at the study area, based on their morphological characteristics. There was a common pattern in the biting activity of the Simulium species found in the study area. The flies were generally more active in the morning than in the early afternoon hours. Also, more flies were caught during the rainy season than in the dry season. There was a statistically significant difference in the distribution of flies between the dry and rainy seasons and between morning and afternoon periods at the two breeding sites $\left\{\mathrm{x}^{2}=0.013<3.841 ; \mathrm{p}<0.05\right\}$.

These findings suggest that the species of Simulium prevalent in the study area exhibit a bimodal pattern in their biting activity. In a bimodal biting pattern, there are early morning and late afternoon peaks, which are separated by a mid-day decline in biting activity (Iboh \& Braide, 1987; Crosskey, 1990; Ubachukwu \& Anyia, 2001).

The tendency of the prevalent flies to bite below the knees confirms earlier reports that members of the S. damnosum complex, S. neavei and S. woodi prefer to bite below the knees (Renz \& Wenk, 1983; Shelley \& Arzube, 1985; Crosskey, 1990).

The highest percentages of parous flies were recorded between April and May. Also, the highest MPBR value of 1150 bites was recorded in April. These findings suggest that April and May constitute both the peak breeding season for the species of black fly and also the period for a heavy transmission of onchocerciasis in the study area. Also, eggs of Simulium species were sighted for the first time in early April at these breeding sites. The absence of larvae of $O$. volvulus in the dissected flies suggests that the ten rounds of ivermectin (Mectizan) distribution was effective in the control of onchocerciasis in the two communities.

It is believed that the species of black fly found in this study are members of the herbicolous group, which prefer to oviposit on living or dead herbs submerged in water (Crosskey, 1990). Therefore, selective destruction of the aquatic plant Pandanus candelabrum, which was the preferred attachment site, may help to disrupt the life cycle of the flies. It is suggested here that this approach may serve as part of useful physical method of control of onchocerciasis in the area.

\section{ACKNOWLEDGEMENTS}

We are grateful to the Monitoring Officer of the Cross River State Onchocerciasis Control Programme, Mr. Asuquo O. Ekwe, for providing information concerning onchocerciasis surveillance in the state. All the staff of PATCEE Computers, Emmanuel, Glory and Ndiyo are remembered for their tireless efforts in typesetting this work.

\section{References}

[1] Adler, P. H., Currie, D. C. \& Wood, D.M. (2004). The Black Flies (Simuliidae) of North America. New York: Cornell University Press.

[2] Atting, I.A. (2000). Studies on the factors influencing the transmission of human onchocerciasis by Simulium damnosum s. 1. in Cross River State, Nigeria. Ph.D. Thesis, University of Calabar.

[3] Barbiero, V. K. \& Trpis, M. (1984). Transmission of onchocerciasis by local black flies on the Firestone Rubber Plantation, Harbel, Liberia. American Journal of Tropical Medicine and Hygiene, 33, 586 - 594.

[4] Butler, J. F. \& Hogsette, J. A. (1998). Black Flies, Simulium species. 8/31/2006, University of Florida IFAS Extension, file://F:Isimulium\Black\%20Flies, \%20Simulium\%20spp.htm

[5] Coluzzi, M., Sabatini, A., Petrarca, V. \& Dideco, M.A. (1979). Chromosomal differentiation and adaptation to human environments in the Anopheles gambiae complex. Transactions of the Royal Society of Tropical Medicine and Hygiene 73, $483-$ 497.

[6] Crosskey, R. W. (1990). The natural history of black flies. Chichester: John Wiley \& Sons Limited.

[7] Cupp, E. W. (1996). Black flies and the agents they transmit. In: B. J. Beaty \& W. C. Marquardt (Eds.), The biology of diseas e vectors (98 - 108). Colorado: University Press of Colorado. 
[8] Currie, D.C. \& Adler, P.H. (2000). Update on a survey of the black flies (Diptera: Simuliidae) from the North West territories and Nunavut project. Arctic Insect News II. http://www.biology. ualberta.ca/bsc/pdf/blackflies.pdf+ecology +of+Simulium + species\&.......

[9] Hamada, N. \& Adler, P. H. (1998). A new species of Simulium (Diptera: Simuliidae) from open areas in Central Amazonia, Brazil. Memórias do Instituto Oswaldo Cruz, Rio de Janeiro, 93 (3), 317 - 325.

[10] Harwood, R. F. \& James, M. T. (1979). Entomology in human and animal health (7 ${ }^{\text {th }}$ edition). New York: Macmillan Publishing Company.

[11] Iboh, C. I. \& Braide, E. I. (1987). The occurrence and distribution of black flies (Simulium species) in Yakurr Clan of Obubra Local Government Area of Cross River State, Nigeria. Ife Journal of Science 2 (1\&2), 1-5.

[12] Leveque, C. (1989). The use of insecticides in the Onchocerciasis Control Programme (OCP) and aquatic monitoring in West Africa. In: P. Bordeau, J. A. Haines, W. Klein \& C. R. Krishna Murti (Eds.), Ecotoxicology and climate (1-20). Chichester: John Wiley \& Sons Limited.

[13] McCreadie, J. W., Adler, P.H. \& Hamada, N. (2005). Patterns of species richness for black flies (Diptera: Simuliidae) in the Nearctic and Neotropical regions. Ecological Entomology 30, $201-209$

[14] Nwoke, B. E. B. (1993). Onchocerciasis control: a training guide in entomological evaluation. Owerri: Imo State University Press.

[15] Renz, A. \& Wenk, P. (1983). The distribution of the microfilariae of Onchocerca volvulus in the different body regions in relation to the attacking behaviour of Simulium damnosum s. 1. in the sudan savannah of northern Cameroon. Transactions of the Royal Society of Tropical Medicine and Hygiene 77, $748-752$.

[16] Service, M.W. (1993). Mosquito ecology: Field-sampling methods, 2nd edition, London: Applied Science Publishers Limited.

[17] Shelley, A.J. \& Arzube, M. (1985). Studies on the biology of Simuliidae (Diptera) at the Santiago onchocerciasis focus in Ecuador, with special reference to the vectors and disease transmission. Transactions of the Royal Society of Tropical Medicine and Hygiene 79, $328-338$.

[18] Ubachukwu, P. O. \& Anyia, A. O. (2001). Studies on the diurnal biting activity pattern of Simulium damnosum complex (Diptera: Simullidae) in Uzo-Uwani Local Government Area of Enugu State, Nigeria. The Nigerian Journal of Parasitology 22 (1\&2), 163 168 .

[19] WorldHealthOrganization(2003)Onchocercavolvulus:biologyandepidemiology.Http://plpnemweb.ucdavis.edu/nemaplex/ Taxadata/Ovolvulus.HTM. 